\title{
IGCP 632, The Jurassic-Cretaceous transition in North Eastern China (western Liaoning and Inner Mongolia): An IGCP meeting and field excursion on the conti- nental Jurassic
}

Jingeng Sha ${ }^{1}$, Yanhong Pan $^{1}$, Enpu Gong ${ }^{2}$, and Vivi Vajda ${ }^{3 *}$

${ }^{1}$ LPS, Nanjing Institute of Geology \& Paleontology, Nanjing 210008, China

${ }^{2}$ Northeastern University, Shenyang 110004, China

${ }^{3}$ Swedish Museum of Natural History, Frescativägen 40, 11418 Stockholm, Sweden, *Corresponding author, E-mail: vivi.vajda@nrm.se

Exposures of strata spanning the Jurassic-Cretaceous boundary occur within several basins in western Liaoning and adjacent Inner Mongolia. These continental successions host world-renowned plant and animal fossils including feathered dinosaurs and the oldest flowering plant, Archaeofructus. The first feathered dinosaurs from northeastern China where found about 20 years ago and created a major impact in science and the media. Since then, many new specimens have been discovered. However, the correlation of the various lithostratigraphic units in this area is complicated due to patchy exposures and the scarcity of radiometric constraints, which pose a challenge to researchers working on these deposits.

To understand the stratigraphy and context of the Jurassic-Cretaceous biota in Liaoning province, the second IGCP-632 symposium was organized in Liaoning, including a two-day presentation (Sep-

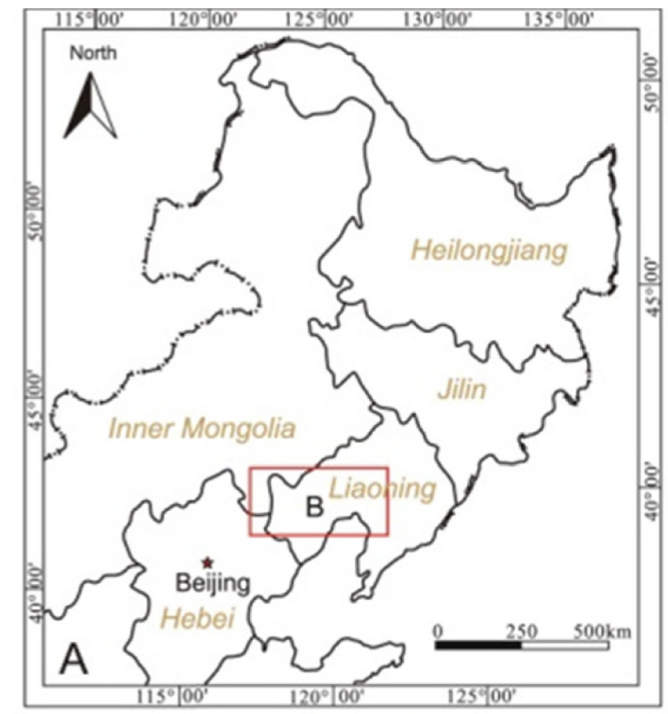

\section{Legend in B}

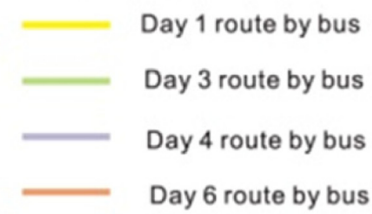

Localities of the stops during the trip

$$
\begin{aligned}
& \text { 1A, Jiangzhangzi } \\
& \text { 2A,B,C, Daohugou village } \\
& \text { 3A, Guancaishan } \\
& \text { 4A, Chaoyang Geopark } \\
& \text { 4B, Zhalanyingzi } \\
& \text { 4C, Haifenggou } \\
& \text { 5A, B, Sanbaoying } \\
& \text { 5C, Sanzui bridge } \\
& \text { 5D, Sihetun } \\
& \text { 5E, Huangbanjigou }
\end{aligned}
$$

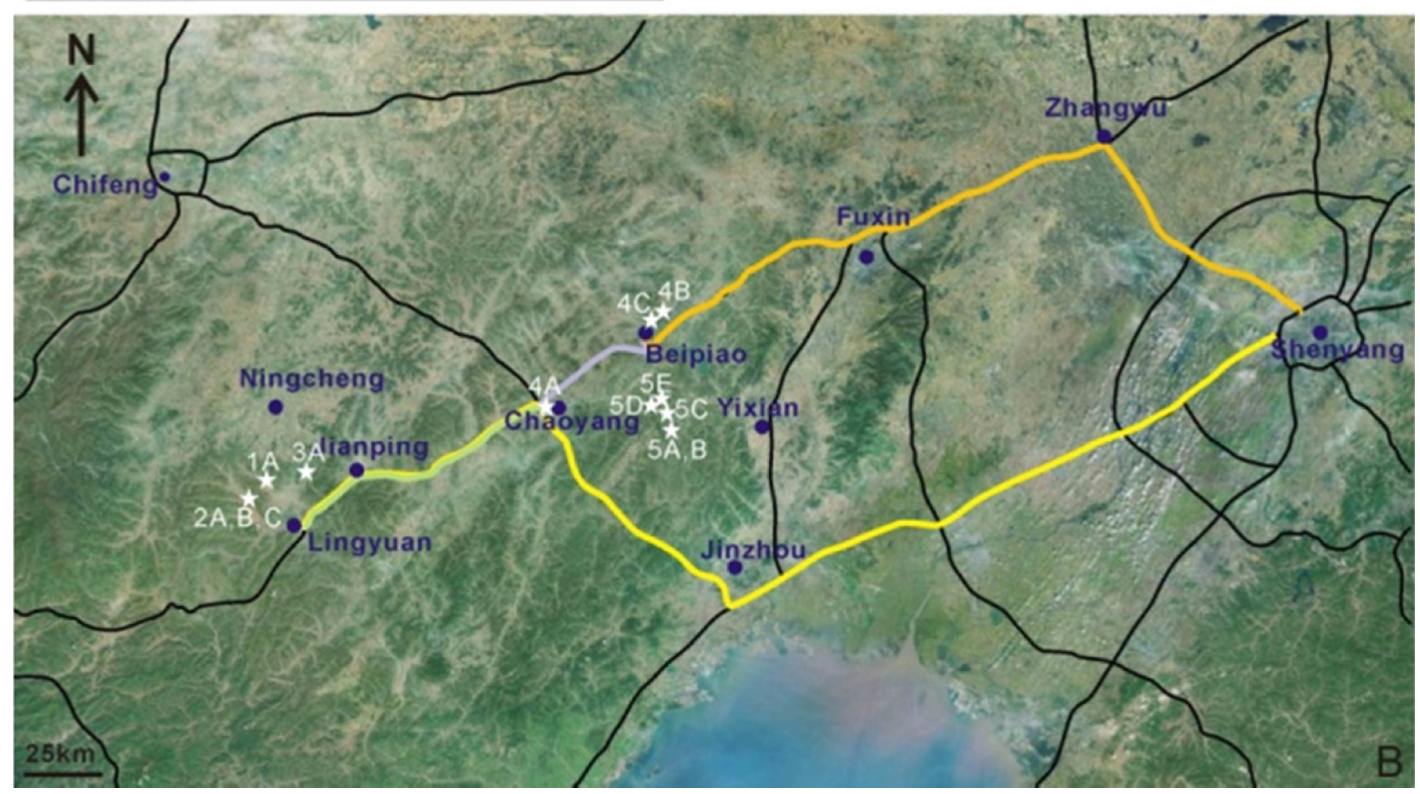

Figure 1. (A) Sketch map over the field excursion area in north-eastern China. (B) enlargement of the field region showing the localities of the field stops. 

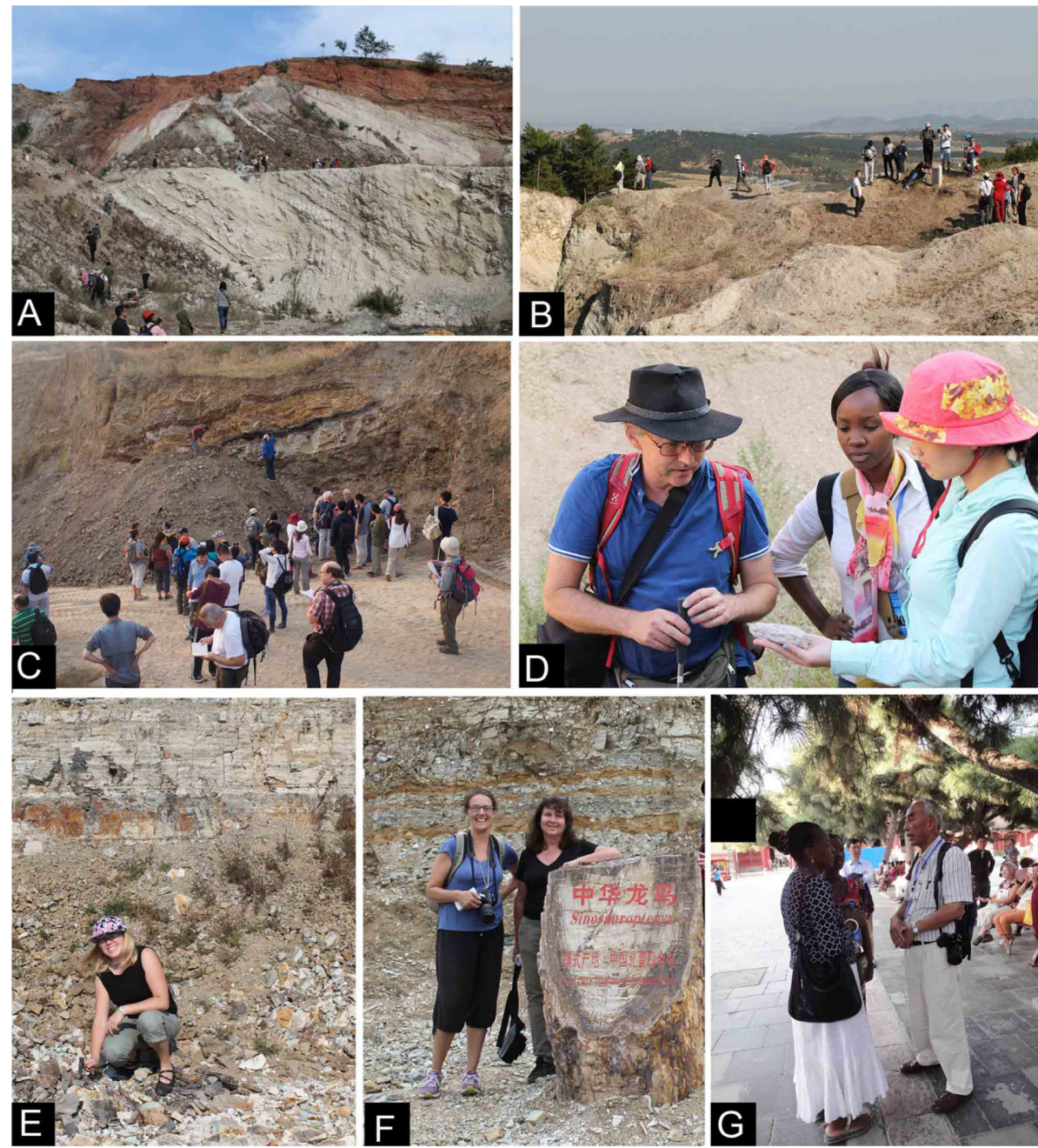

Figure 2. Photographs of field trip participants and sites during the IGCP-362 field trip. (A) The Jiangzhangzi Section, showing the unconformity between the Daohugou fossil beds and the Tuchengzi Formation; (B) The intersection where the three large provinces Inner Mongolia, Liaoning and Hebei meet with Jurassic deposits exposed; (C) Coal layer within the Beipiao Formation; (D) Yanhong Pan, Stephen McLoughlin, Anna and Emma Msaky; (E) Olena Shevchuk studying fossils at the Sihetun museum section; (F) Vivi Vajda and Anna Lindström by the Sinosauropteryx monument at Shihetun; (G) Sha Jingeng and Emma Msaky involved in a scientific discussion at the Campus outside the Science building of the Northeastern University in Shenyang.

intracontinental orogenic system, the Yanshan Movement, and creating a new basin-range system in east Asia.

Vivi Vajda presented new results (Peterffy et al., 2015; Vajda et al., 2016) where she comprehensively analyzed the end-Triassic mass extinction and aftermath and its causal mechanisms, particularly stressing the affects of Jurassic volcanism in disrupting the major ecosystems but also its importance for fossilization.

Jingeng Sha presented the stratigraphy and important palaeogeographic implications of the Early Cretaceous unconformity, with a comprehensive analysis comparing sites from China, Korea, Japan and the Far East of Russia.

Zhonghe Zhou summarized and compared the Jurassic vertebrate assemblages, the so called Yaniao Biota and the Early Cretaceous Jehol Biota. Ge Sun and Shenghui Deng described Jurassic floras from the Junggar Basin, nortwestern China and the Xilinhot Basin of Inner Mongolia, focusing on the palaeoclimatic and paleophytogeographic contexts.

Xin Xu presented new data on terrestrial ecosystems from Northern China comprising the Mid-Late Jurassic transition interval. The role of insects in the Mesozoic ecosystems of northeastern China was presented by Dong Ren and Meizu Wang.

Paul Olsen introduced how to use Earth's sedimentary record to map the chaotic evolution of the solar system, while Franz Fürsich and Yanghong Pan introduced the invertebrate and fish taphonomy of Early Cretaceous lake deposits of northeastern China. Diying Huang presented the evolution of insect-vertebrate associations based on the evidence from Mesozoic successions of northeastern China.

Within the field of stratigraphy, both methods and new advances were widely discussed, e.g.,

tember $12-13,2015)$ and a six-day field excursion in western Liaoning and adjacent Inner Mogolia after the symposium (September 1419, Figs. 1 and 2). The symposium was held in Shenyang, the capital of Liaoning and organized by the Department of Geology at Northeastern University under the leadership of professor Enpu Gong and with the help of many of his students. The opening ceremony (Fig. 3) was held at Northeastern University in Shenyang and the head of the university gave the opening speech. The symposium was very successful with approximately 150 participants from 23 countries, 56 talks and 22 poster presentations including six invited plenary and eight keynote talks, involving continental Jurassic and Early Cretaceous ecosystems, stratigraphy, palaeogeography, palaeoclimate, geochemistry, tectonics, volcanism, and the geological orrery.

Shuwen Dong demonstrated the processes of continental convergence of the Palaeo-Pacific Plate from the southeast, Qiangtang and Lhasa blocks from southwest, and Siberia Plate from north, causing the
William Wimbledon reported on the latest advances concerning the definition of the Jurassic-Cretaceous boundary. Su-Chin Chang detailed the high-precision radiometric-dating methods and obtained ages for the Mesozoic fossil-rich formations in East Asia. Shin-ichi Sano presented his new view of the Tetori Group, Japan (a famous succession of alternating marine and non-marine beds). Yongqing Liu presented the stratigraphy, sedimentary palaeogeography and palaeoecology of the Jurassic-Cretaceous transition of north and northeastern China.

Additionally, interesting new results on the fossil fauna and flora of the Daohugou fossil beds and the Jehol Biota were presented. New, refined age determinations by $\mathrm{Pb}-\mathrm{U}$ on zircons from ash-deposits within the Jehol Group were presented and amazing new discoveries of animals and plants are now being analyzed using increasingly sophisticated methods. Among other novelties, participants heard the sound of a Jurassic cricket - recreated by computer-generated acoustics derived from 3-D scanning of the stridulatory organs of a well-preserved extinct 


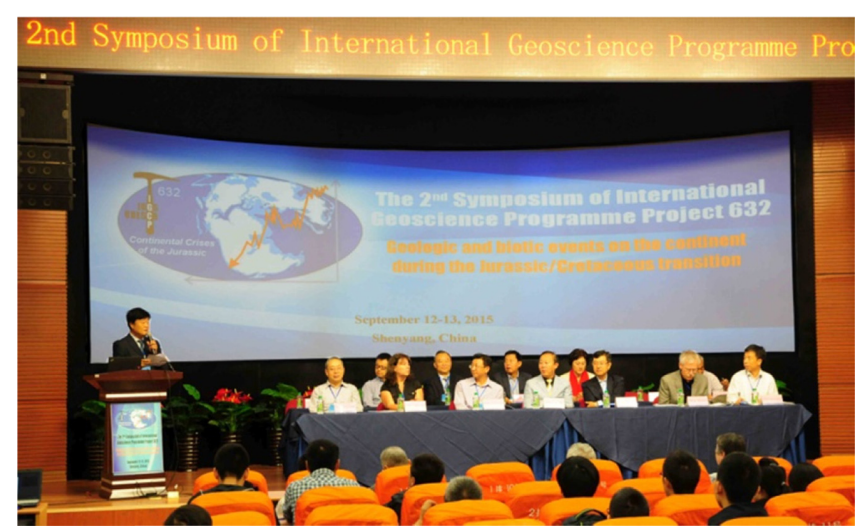

Figure 3. Opening speech by Professor Enpu Gong at the Northeastern University in Shenyang.

orthopteran that thrived in the Daohugou Jurassic ecosystem. Another presentation revealed the bizarre gigantic fossil lice that reached up to $5 \mathrm{~cm}$ long and that probably fed on dinosaurs. Yet other talks dealt with the most famous findings from the Jehol Biota: the feathered dinosaurs, where the color of the plumage has been recreated by analyses of the metal contents of the fossil feathers. Although the focus of the symposium concerned the Jurassic-Cretaceous successions of China, a broad range of international contributions were presented.

Stephen McLoughlin presented a Jurassic "lagerstätte" from Australia the Talbragar biota, primarily known for its exquisitely preserved fish fossils, and he compared with the coeval Chinese Daohugou biota.

Others presented new data on fossil amber with exceptionally preserved insects from Lebanon to the Jurassic faunas and floras of Australia, Sweden, the Ukraine, Britain, Russia, Slovakia, and Tanzania, amongst others. The very successful symposium was followed by a six-day excursion in Western Liaoning and parts of Inner Mongolia.

There are several continental basins in this area filled with volcanic-sedimentary sequences and the lithology comprises mainly sandstones, siltstones, mudstones and basal conglomerates, or coal layers interbedded with volcanic ash deposits (e.g., Gu, 1982; Sha, 2007; Sha et al., 2007, 2012; Liu et al., 2012). The excursion was organized and led by E. Gong and Y. Pan, C. Guang, R. Guo and J. Sha together with

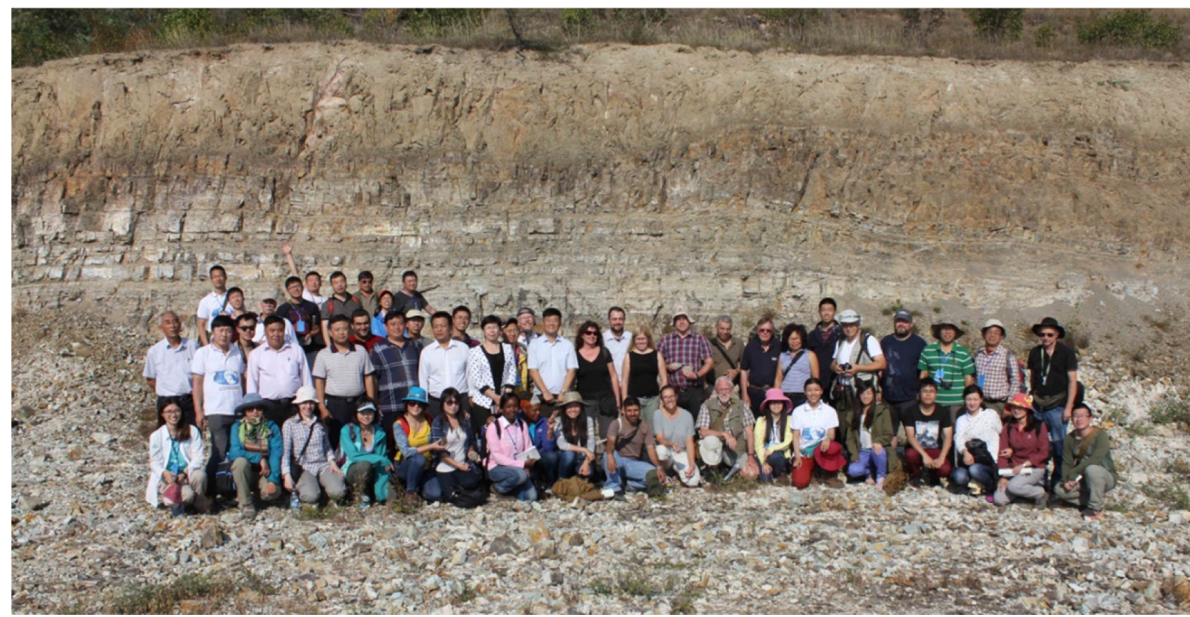

Figure 4. Group photo of IGCP-362 field trip participants at the Guancaishan Section, in Muyingzi Village, a locality best known for its rich occurrence of the salamander Chunerpeton tianyiensis of an Oxfordian (Late Jurassic) age. geology students from the Northeastern University of Shenyang. The contribution and help from the local authorities in each region was impressive, and the group of 45 was guided and given access to local museums and localities with world-famous fossil assemblages (Fig. 4).

We left Shenyang early morning the 14th of September headed for the Daohugou fossil beds within the Ningcheng Basin. The exact stratigraphic position of these beds is unclear and has caused debates. The Daohugou localities have been known since 1998 (Fig. 2) when local farmers began to recover fossils, such as vertebrates, conchostracans, arachnids, insects, bivalves, and plants (Fig. 5). Although there is, so far, no radiometric dating of from the Daohugou beds, various dates obtained by both $\mathrm{Ar}^{40} / \mathrm{Ar}^{39}$ and U-Pb SHRIMP techniques on the volcanic ash and lava beds over- and underlying the Daohugou fossil-bearing deposits show that these strata are between Bathonian and Kimmeridigian age, ranging from $168 \mathrm{Ma}$ to $152 \mathrm{Ma}$, but mainly 166-159 Ma, indicating a Callovian-Oxfordian age (Chen et al., 2004; He et al., 2004; Liu et al., 2006). It merits attention that the latest dating results of SHRIMP U-Pb and SIMS U-Pb of zircons from the "corresponding" Daohugou fossil-bearing lacustrine deposits in Linglongta of Jianchang County, indicate ages between 161 and $159 \mathrm{Ma}$, i.e., limited to the Oxfordian (Hu et al., 2009; Liu et al., 2012; Wang, L. et al., 2013). The fauna is represented by diverse insect assemblages (e.g., Gao and Shubin, 2003; Ren et al., 2009, 2010; Wang, B. et al., 2013; Cai et al., 2014; Huang, 2014; Yan et al., 2014; Zhang, 2015 and references therein) lizards, salamanders (Fig. 6; that have been used as stratigraphical markers), dinosaurs (including the feathered ones) and early mammals (e.g., Wang, X. et al., 2002b; Sullivan et al., 2014). The fossil plants typical of the Daohugou beds include, amongst others, the cupressaceous conifer Yanliaoa, and the bennettitaleans Anomozamites, Cycadolepis, and Pterophyllum, and the ginkgo Yimaia. This flora has been interpreted as Middle Jurassic (Zhou et al., 2007) and is significantly different from that of the Jehol Group. Most importantly, the Daohugou succession represents a time slot when birds were apparently just diverging from the rest of the dinosaurs. Although the Jehol Biota includes abundant bird fossils, there are a few examples from older deposits, with the only well-described assemblage being the famous Archaeopteryx of Solnhofen, Germany. An interesting discovery at Daohugou was the very "bird-like" dinosaur Anchiornis (Fig. 7) (Hu et al., 2009). The Daohugou beds are older than other major deposits with bird fossils and the findings so far are very promising for Daohugou to become a "new Solnhofen".

After leaving our luggage in our hotel in Lingyuan, we spent the afternoon in the field studying the Daohugou fossil beds at the abandoned quarry at Jiangzhangzi (Fig. 2). The lacustrine deposits exposed in the quarry are known to contain similar fossil assemblages to those at the type locality near Daohugou Village. The beds in the quarry showed to be fossiliferous and it did not take many minutes before our group found the first charcoalified plant remains, bennettitalean leaves and conchostrachans. The geology is interesting at this site because the unconformity between the Daohugou fossil beds and the Tuchengzi 


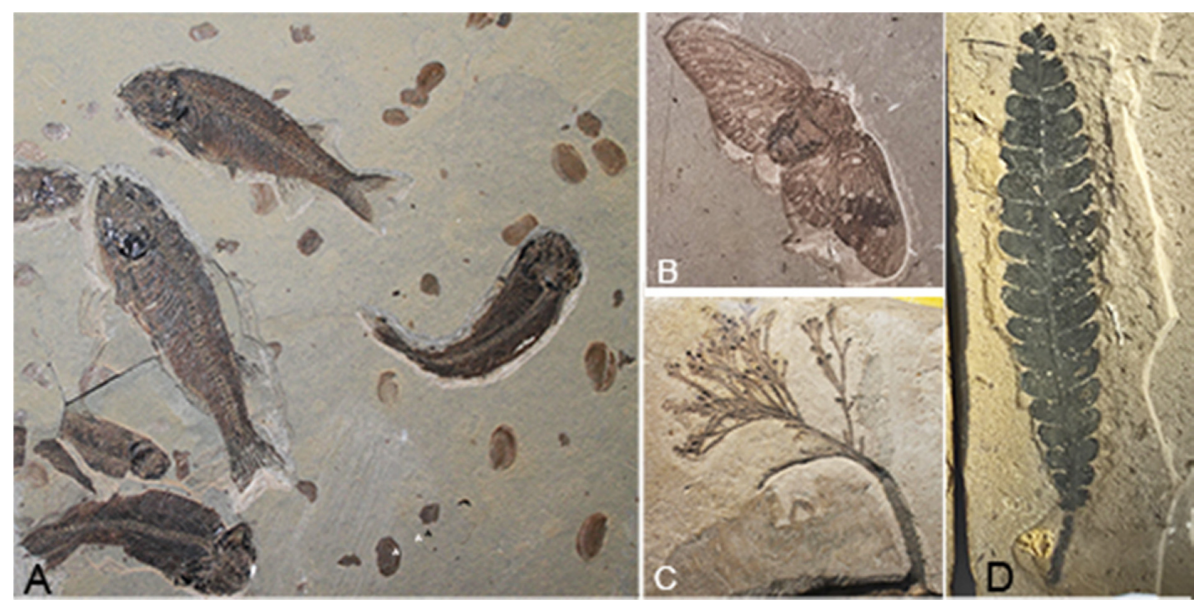

Figure 5. Fossils displayed at the museum in the Daohugou Geopark. (A) Fish, Lycoptera muroii Takai and conchostrachans; (B) Early Cretaceous Lepidoptera, moth; (C) Middle Jurassic conifer, Yanliaoa sinensis Pan; (D) Late Jurassic Bennettite, Anomozamites sp.

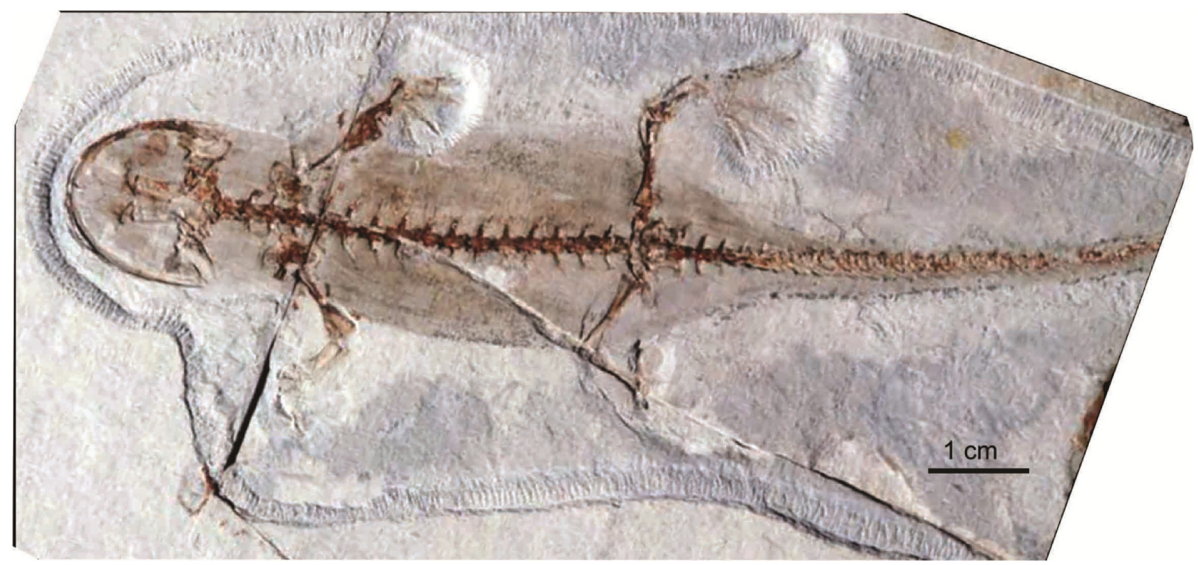

Figure 6. Salamander, Liaoxitriton daohugouensis IVPP V14062 (Wang, Y., 2004).

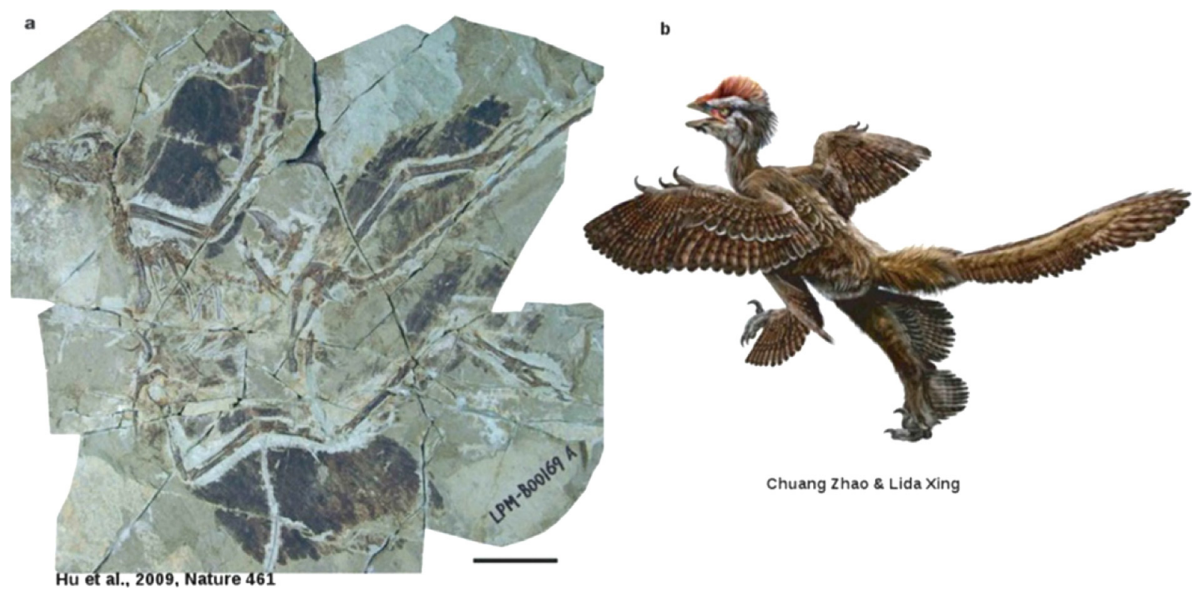

Figure 7. Anchionis huxleyi found in the Tiaojishan Formation of Daxishan (= large western hill), Linglongta Town, Jianchang Liaoning (Hu et al., 2009), Scale bar $=5 \mathrm{~cm}$. Photo provided by Dongyu $\mathrm{HU}$.

Formation is visible near the rim of the quarry.

On September $15^{\text {th }}$, participants in the field trip studied the typical Daohugou exposures near Daohugou Village and numerous fossils were found in the laminated beds. At these sites the Daohugou fossil beds comprise a 100 to 150 -m-thick succession of grey-white lami- nated mudstones, siltstones and conglomerates, with tuffs (e.g., Wang, X. et al., 2005; Gao and Ren, 2006) and are interpreted to be part of the Lanqi (Tiaojishan) and/or Haifanggou formations. Some scientists refer the beds to their own formation, the Daohugou Formation (Zhang, 2015).

Lunch was provided at the Daohugou museum, a field museum that provides some unique insights to the local geology. The museum is displayed as a covered quarry and the back-wall of the museum constitutes a cleaned rock face exposing a large section of the Daohugou beds with lithological explanations and stratigraphical information. Fossils from the beds are displayed at the "quarry" floor, and both fixed and animatronic reconstructions of the various vertebrates, amongst those the feathered dinosaurs, salamanders, lizards, and early mammals, are displayed based on the fossil findings within these beds. We ended the day studying additional Daohugou exposures along the valley.

The third day of our field trip, September $16^{\text {th }}$, we spent at the Guancaishan Section, in Muyingzi Village, a locality best known for its rich occurrence of the salamander Chunerpeton tianyiensis of Oxfordian (Late Jurassic) age. The dating is based on a lava bed overlying the fossil-bearing beds with a U-Pb SHRIMP date of $157 \pm 3.3 \mathrm{Ma}$ (Liu et al., 2006a, 2006b). The evening was spent in the interesting town of Chaoyang.

The remainder of the field excursion proceeded up-section through conglomerates and volcanic successions until reaching the Cretaceous Jehol Group.

The term "Jehol Series" was introduced by Grabau in 1923 to comprise the Lower Cretaceous continental sedimentary strata in Lingyuan County, western Liaoning. The term was later changed to the "Jehol Group" by Gu in 1962 and described as a major stratigraphic unit of western Liaoing and subdivided into three formations; the lower volcanic formation, Jiufotang Formation and the upper volcanic formation, but later it was subdivided into the Yixian Formation, Jiufotang Formation and Fuxin Formation by $\mathrm{Gu}$ (e.g., Gu, 1982). There are major ongoing discussions concerning the stratigraphic subdivision and correlation of the Mesozoic strata in western Liaoning, northeastern China and eastern Inner Mongolia, and eastern Asia in general, under the framework of the Jehol Group (e.g., Jiang and Sha, 2006; Sha, 2007; Sha et al., 2012 and references therein; Zhang and Sha, 2012; Pan et al., 2013). However, there are also some authors (e.g., Zhang et al., 2010) that include the Yixian, 


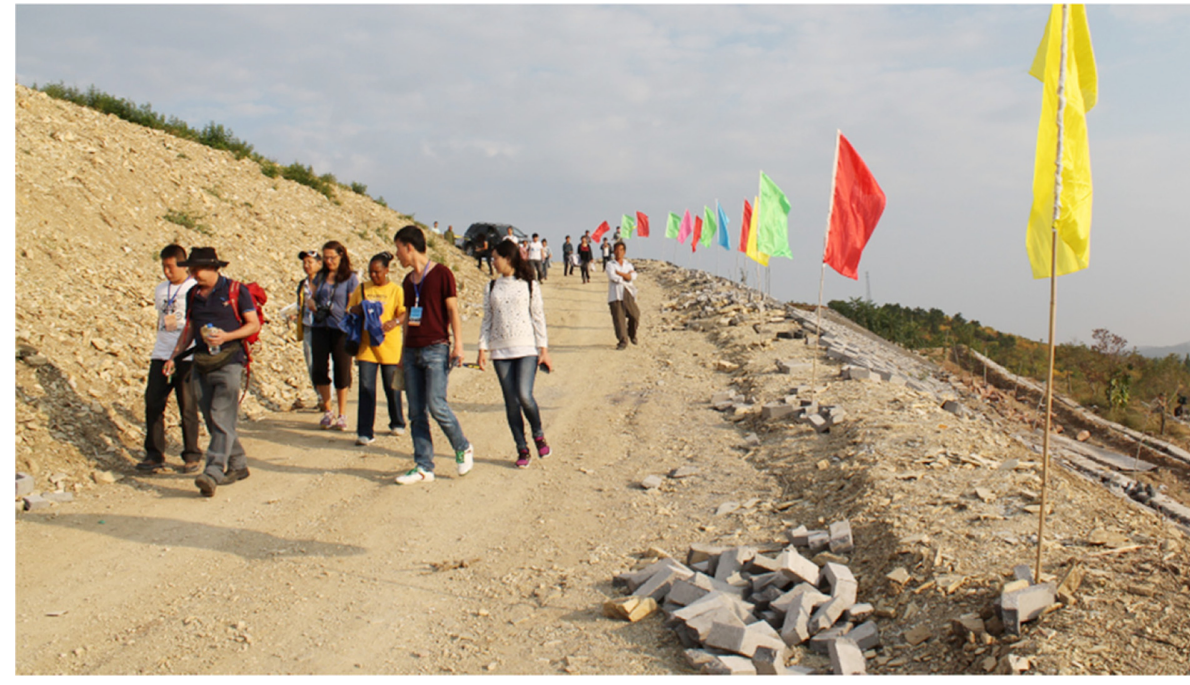

Figure 8. On way back from last excursion site at Huangbanjigou, where another fossiliferous facies within the Jianshangou Bed is exposed.

Jiufotang and the "Dabeigou" formations (as named in Hebei Province) within the Jehol Group. Ongoing lithostratigraphic and biostratigraphic research will ultimately clarify the appropriate stratigraphic relationships.

The tour group obtained its first sight of the Jehol successions and its impressive biota when visiting the Sihetun Museum, a major highlight where the successions comprising the Yixian Formation hosting the world-famous Jehol Biota was displayed. The Sihetun area is one of the most famous fossil localities of western Liaoning. The Yixian Formation exposed here consists of weakly laminated to finely bedded siliciclastic sediments, mainly low-energy sandstones, and shales, intercalated with extrusive basalts and tuffs and cross-cut by sporadic dykes and sills (Sha, 2012 and references therein). The main fossiliferous strata are represented within the Jianshangou Bed. The excursion group spent the afternoon searching through the rock debris (without using hammers) in the quarry nearby the museum where numerous insect, conchostracans and even small vertebrates could be seen. Importantly, the conchostrachans are significantly larger in these beds compared to those from the older Daohugou Biota. The Sihetun Museum hosts an impressive and diverse assemblage of fossils summarized in books by Sun et al. (2001, 2011), Chang et al. (2003, 2005) and Ji et al. (2004). Key among the fossils are the type specimen of the Amphibian Mesorphyne beipiaoensis, turtles, squamates, chorestoderes, pterosaurs, birds, mammals and plants (Hyrcatha decussate). The field excursion of the second symposium of IGCP-632 culminated with a visit to the remarkable Huangbanjigou Section, where a welcome committee received us with multicolored flags as we drove up the winding road to the exposures (Fig. 8). Finely laminated tuffaceous sandstones, siltstones, and mudstones, yielding abundant fossils including, pterosaurs, fish, insects, malacostracan crustaceans, may fly larvae and, most importantly, the oldest angiosperm Archaefructus liaoningensis, have been collected here.

The group found several excellent insect and fish fossils, which were handed over to the local authorities. We spent the last night with a discussion on the fossil biota and age of the field sites before heading back to Shenyang the next morning.
The IGCP-632 symposium and the following field trip provided us all with important knowledge of the Mesozoic exposures of Liaoning, we obtained new insights into the local geology, sedimentology, fossil preservation and abundance, stratigraphy and the difficulties integrating these characteristics into a synthetic stratigraphic scheme within a robust palaeoenvironmental context. With these insights, we are prepared to move forward, hopefully adding new scientific data and interpretations to these world-renowned successions.

\section{Acknowledgements}

The authors thank the referee for valuable comments improving the manuscript. The meeting could not have been held without the contribution of following sponsors:

International Geoscience of Program of UNESCO-IUGS (IGCP)

International Subcommission on Jurassic Stratigraphy (ISJS)

National Natural Science Foundation of China (NSFC)

Northeastern University

Department of Education of Liaoning Province

Department of Land and Resources of Liaoning Province

Bureau of Fossil Protection and Administration of Liaoning

Liaoning Association for Science and Technology

Paleontological Museum of Liaoning

Geological Society of Liaoning

Benxi Branch of the Geological Museum of China

China National Committee of Stratigraphy

General Office of National Paleontological Experts Committee

China Fossil Preservation Foundation (CFPF)

Nanjing Institute of Geology \& Palaeontology, CAS

Institute of Vertebrate Paleontology and Paleoanthropology, CAS

Nanjing University

Palaeontological Society of China

\section{References}

Cai, C., Thayerb, M.K., Engelc, M.S., Newtonb, A.F., Ortega-Blancoc, J., Wang, B., Wang, X., and Huanga, D., 2014, Early origin of parental care in Mesozoic carrion beetles: PNAS, v.11, pp. 114170-14174.

Chen, W., Ji, Q., Liu, D., Zhang, Y., Song, B., and Liu, X., 2004, Isotope geochronology of the fossil-bearing beds in the Daohugou area, Ningcheng, Inner Mongolia: Geological Bulletin of China, v.23, pp. 11651169. (in Chinese with English summary)

Chang, M.M., Wang, Y.Q., and Wang, Y. (eds.), 2001, The Jehol Biota: Scientific and Technical Publishers, Beijing, 150 pp. (in Chinese)

Chang, M.M., Wang, Y.Q., Wang, Y. (eds.), 2003, The Jehol Biota: Scientific and Technical Publishers, Beijing, 207 pp.

Gao, K., and Ren, D., 2006, Radiometric dating of ignimbrite from Inner Mongolia provides no indication of a post-Middle Jurassic age for the Daohugou Beds: Acta Geologica Sinica, 80, pp. 42-45.

Gao, K., and Shubin, N. H., 2003, Earliest konown crown-group salamanders: Nature, v.422, pp. 424-428.

Grabau, A.W., 1923, Cretaceous mollusa from North China: Bulletin of Geological Survey of China, v.5, pp. 183-197.

Gu, Z., 1962, The Jurassic and Cretaceous of China: Science Press, Beijing, 88 pp. (in Chinese) 
Gu, Z., 1982a, Distribution and development of non-marine Mesozoic bivalves and formations in China: Scientia Sinica (Series B), v.25, pp. 438-452.

Gu, Z., 1982b, Correlation chart of the Jurassic in China with explanatory text, In: Nanjing Institute of Geology and Palaeontology, Academia Sinica, ed., Stratigraphical Correlation Chart in China with Explanatory Text. Science Press, Beijing, pp. 223-240. (in Chinese)

He, H., Wang, X., Zhou, Z., Zhu, R., Jin, F., Wang, F., Ding, X., and Boven, A., 2004, 40Ar/39Ar dating of ignimbrite from Inner Mongolia, northeastern China, indicates a post-Middle Jurassic age for the overlying Daohugou Bed: Geophysical Research Letters, v.31, L20609.

Hu, D., Hou, L., Zhang, L., and Xu, X., 2009, A pre-Archaeopteryx troodontid theropod from China with long feathers on the metatarsus: Nature, v.461, pp. 640-643.

Huang, D., 2014, Trace back the origin of recent insect orders-evidence from the Middle Jurassic Daohugou Biota: Science Foundation in China, v.22, pp. 34-42.

Ji, Q. et al., 2004, Mesozoic Jehol Biota of Western Liaoning: Geological Publishing House, Beijing, 375 pp. (in Chinese)

Jiang, B.Y., and Sha, J.G., 2006, Late Mesozoic stratigraphy in western Liaoning, China: A review: Journal of Asian Earth Sciences, v.28, pp. 205-217.

Liu, Y., Liu, Ya., Ji, S., and Yang, Z., 2006a, U-Pb zircon age for the Daohugou biota at Ningcheng of Inner Mongolia and comments on related issues: Chinese Science Bulletin, v.51, pp. 2634-2644.

Liu, Ya., Liu, Y., and Zhang H., 2006b, LA-ICPMS zircon U-Pb dating in the Jurassic Daohugou beds and correlative strata in Ningcheng of Inner Mongolia: Acta Geologica Sinica, v.80, pp. 733-742.

Liu, Y., Kuang, H., Jiang, X., Peng, N., Xu, H., and Sun, H., 2012, Timing of the earliest known feathered dinosaurs and transitional pterosaurs older than the Jehol biota: Palaeongeography, Palaeoclimatology, Palaeoecology, v.323-325, pp. 1-12.

Pan, Y., Sha, J., Zhou, Z., and Fürsich, F., 2013, The Jehol Biota: Definition and distribution of exceptionally preserved relicts of a continental Early Cretaceous ecosystem: Cretaceous Research, v. 44, pp. 30-38.

Peterffy, O., Calner, M., and Vajda, V., 2016, Early Jurassic microbial mats A potential response to reduced biotic activity in the aftermath of the end-Triassic mass extinction: Palaeogeography, Palaeoclimatology, Palaeoecology. http://dx.doi.org/10.1016/j.palaeo.2015.12.024

Ren, D., Labandeira, C.C., Santiago-Blay, J.A., Rasnitsyn, A., Shih, C., Bashkuev, A., Logan, M.A.V., Hotton, C.L., and Dilcher, D., 2009, A probable pollination mode before angiosperms: Eurasian, Long-Proboscid Scorpionflies: Science, v.326, pp. 840-847.

Ren, D., Shih, C., Gao, T., Yao, Y.Z., Zao, Y.Y. et al., 2010, Silent Stories: Insect fossil treasures from dinosaur era of the Northeastern China: Science Press, Beijing, 322 pp.

Sha, J., 2007, Cretaceous stratigraphy of northeast China: non-marine and marine correlation: Cretaceous Research, v.28, pp. 146-170.

Sha, J., Pan, Y., Wang, Y., Zhang, X., and Rao, X., 2012, Non-marine and marine stratigraphic correlation of Early Cretaceous deposits in NE China, SE Korea and SW Japan, non-marine molluscan biochronology, and palaeogeographic implications: Journal of Stratigraphy, v.36, pp. 357-381. (in English with Chinese Abstract)

Sha, J., Yao, X., Hirano, H., Pan, Y., Zhang, X., and Wang, Y., 2007, Correlation amongst the Lower Cretaceous Longzhaogou, Jixi, and Jehol groups in northeastern China: a review: Beringeria, v.37, pp. 189-202.

Sullivan, C., Wang, Y., Hone, D.W.E., Wang, Yu., Xu, X., and Zhang, F., 2014, The vertebrates of the Jurassic Daohugou Biota of northeastern China: Journal of Vertebrate Paleontology, v.34, pp. 243-280.

Sun, G., Zheng, S.L., Dilcher, D.L. et al., 2001, Early Angiosperms and their Associated Plants fromWestern Liaoning, China: Scientific and Technological Education Publishing House, Shanghai, 227 pp. (in Chinese and English)

Sun, G., Zhang, L.J., Zhou, C.F. et al., 2011, The fossil record of three billion years in Liaoning, China: Scientific and Technological Education Publishing House, Shanghai, 176 pp.

Vajda, V., Linderson, H., and McLoughlin, S., 2016, Disrupted vegetation as a response to Jurassic volcanism in southern Sweden. in Kear, B.P., Lindgren, J., Hurum, J.H., Milán, J., and Vajda, V., eds., Mesozoic Biotas of Scandinavia and its Arctic Territories. Geological Society of London, Special Publications, v.434. http://doi.org/10.1144/SP434.17.

Wang, B., Zhang, H., Jarzembowski, E.A., Fang, Y., and Zheng, D., 2013, Taphonomic variation of fossil insects: A biostratinomoc study of palaeontinidae and tettigarctidae (insect: Hemiptera) from the Jurassic Daohugou lagerstätte: Palaios, v.28, pp. 233-242.

Wang, L., Hu, D., Zhang, L., Zheng, S., He, H., Deng, C., Wang, X., Zhou, Z., and Zhu, R., 2013, SIMS U-Pb zircon age of Jurassic sediments in Linglongta, Jianchang, western Liaoning: constraint on the age of oldest feathered dinosaurs: Chinese Science Bulletin, v.58, pp. 1346-1353. (in Chinese with English summary)

Wang, X., Zhou, Z., Zhang, F., and Xu, X., 2002, A nearly completely articulated rhamphorhynchoid pterosaur with exceptionally well-preserved wing membranes and "hairs" from Inner Mongolia, northeast China: Chinese Science Bulletin, v.47, pp. 226-230.

Wang, X., Zhou, Z., He, H., Jin, F., Wang, Y., Zhang, J., Wang, Y., Xu, X., and Zhang, 2005, Stratigraphy and age of the Daohugou Beds in Ningcheng, Inner Mongolia: Chinese Science Bulletin, v.50, pp. 2369 2376.

Yan, E.V., Wang, B., Ponomarenko, A.G., and Zhang, H., 2014, The most mysterious beetles: Jurassic Jurodidae (Insecta: Coleoptera) from China: Gondwana Research, v.25, pp. 214-225.

Zhang, J., 2015, Archisargoid flies (Diptera, Brachycera, Archisargidae and Kovalevisargidae) from the Jurassic Daohugou biota of China, and the related biostratigraphical correlation and geological age: Journal of Systematic Palaeontology, v.13, pp. 857-881.

Zhang, H., Wang, B., and Fang, Y., 2010, Evolution of insect diversity in the Jehol Biota: Science China (Earth Sciences), v.53, pp. 1908-1917.

Zhang, X., and Sha, J., 2012, Sedimentary laminations in the lacustrine Jianshangou Bed of the Yixian Formation at Sihetun, western Liaoning, China: Cretaceous Research, v.36, pp. 96-105.

Zhou, Z., Zheng, S., and Zhang, L., 2007, Morphology and age of Yimaia (Ginkgoales) from Daohugou village, Ningcheng, Inner Mongolia, China: Cretaceous Research, v.28, pp. 348-362. 